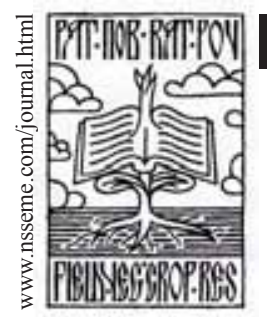

Genetic Resources / Genetički resursi

Ratar. Povrt. / Field Veg. Crop Res. 48 (2011) 1-6 review article / pregledni rad

\title{
Conservation and Breeding of Ornamental Lathyrus Species
}

\author{
Roger Parsons · Aleksandar Mikić
}

received / primljeno: 19.10.2010. accepted / prihvaćeno: 27.11.2010.

(C) 2011 IFVC

\begin{abstract}
Summary: A considerable number of diverse ornamental forms of Lathyrus odoratus exist which require careful conservation if they are not to be lost. Other ornamental Lathyrus species may have potential for increasing their diversity. A seedbank has been established in the United Kingdom to conserve this diversity and make the material readily available to researchers and growers throughout the world. Conventional hybridisation provides an opportunity for the existing diversity in $L$. odoratus to be extended. Opportunities also exist to create improved decorative forms and new colours in some other species through intra-specific hybridisation. Inter-specific hybridisation within the genus is in its infancy but early results suggest exciting improvements might be introduced by this method. Such work might also provide benefits for comparative genomics in the tribe Fabeae.
\end{abstract}

Key words: conservation, hybridisation, Lathyrus, plant breeding, seedbank, seed production, sweet pea

\section{Historical Overview}

Although Lathyrus species have been grown since ancient times, their cultivation for ornamental purposes can be traced to the sending of the sweet pea, Lathyrus odoratus, from Sicily to England and the Netherlands in 1699. This species quickly became widely distributed for its scent and decorative flowers. The typical species has maroon and violet bicoloured flowers but within 20 years a pink and white bicolour cultivar and a white cultivar existed. By 1800, six colours were known and continued to steadily increase but there is no indication that intentional crossing of cultivars was occurring before 1860. Such novel flower colours have led to a perception that $L$. odoratus has a high mutation rate but there is no evidence to support this.

The few decades from 1860 onwards saw several plant breeders actively crossing cultivars to produce new ones, greatly widening the colour range and improving the size and vigour of earlier colours. One of these, Henry Eckford, coined the term 'Grandiflora' for his Sweet

R. Parsons $(\bowtie)$

Roger Parsons Sweet Peas, Primrose Cottage, Clayton Lane, Bracklesham Bay, Chichester PO20 8JQ United Kingdom

e-mail: roger@rpsweetpeas.co.uk

A. Mikić

Institute of Field and Vegetable Crops, Maksima Gorkog 30, 21000 Novi Sad, Serbia
Peas to promote their improved size compared with earlier material. By 1900, dozens of new cultivars were available (Fig. 1). In addition, other Lathyrus species were being grown as part of a wider interest in discovering the world's flora.

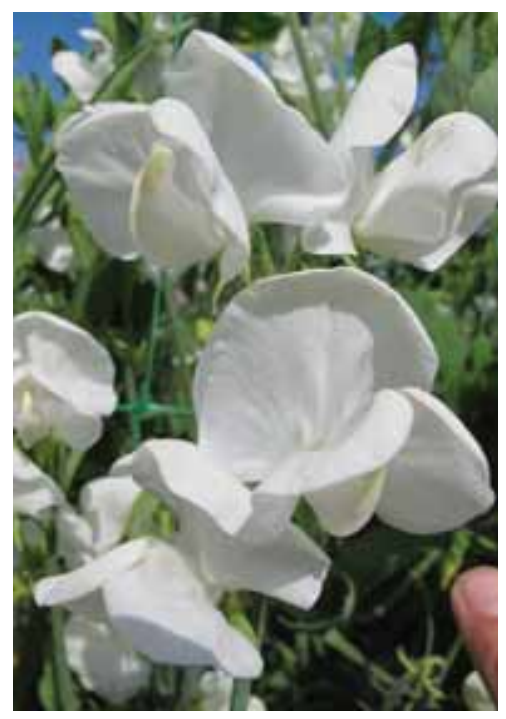

Fig. 1. L. odoratus 'Dorothy Eckford' has normal flower form

Slika 1. Sorta mirisnog grahora Doroti Ekford poseduje običnu veličinu cveta 
In 1900, a new form of $L$. odoratus was seen that caused a sensation. It was a cultivar with larger, frilly petals and a longer raceme, making it much more attractive to florists than the smaller, plain petals of the Grandiflora cultivars. This first large, frilly cultivar was named 'Countess Spencer' and all subsequent cultivars with this flower form have been known as Spencer sweet peas (Parsons 2000). This new flower form, together with the discovery of Mendel's research, led to a frenzy of breeding new sweet peas and a considerable increase in growing sweet peas for cut flowers and by amateur gardeners. By 1910, California alone was growing around 400 ha of sweet pea seeds and had become the main centre of seed production (Wright 1912). The 20th century saw considerable refinement of Spencer sweet peas by plant breeders to improve flower size, purity of colour, raceme length, and vigour. They also introduced new types having early flowering characteristics, dwarf and intermediate height, non-tendril (multijugate) leaves, and additional petals. As a result of all this work, the vigour of plants and associated raceme length and flower size all increased (Parsons 2011).

\section{Conservation of Lathyrus Species and Cultivars}

Cultivation of $L$. odoratus cultivars has taken place in many parts of the world and remains significant. Perhaps the main activity is in cut flower production, often to meet local markets. For example, most northern European countries have at least one producer of cut flower sweet peas. Although less popular in the UK nowadays because of their short vase life, they remain popular as a winter cut flower crop in Japan. By contrast, few sweet peas are grown by amateur gardeners in Japan but they remain a popular flower with UK gardeners. Seed production has become more diversified, with New Zealand rising as an important secondary centre of seed production (Parsons 2009).

A problem of field scale production of $L$. odoratus seed is that the Spencer flower form is recessive to normal form. Records of petal size and plant vigour show that Grandiflora cultivars, with normal flower form, have not changed significantly during the last 100 years of seed generations but Spencer cultivars are frequently seen to revert to clamped keels, either with normal flower form and size or with an intermediate size and form. These intermediate flowers have a clamped keel and frilly petals and have been called SemiGrandiflora type (Parsons 2011) (Fig. 2). When cropping a cultivar on a field scale, it is easy to remove any plants with the wrong flower colour but reversion in flower form, or other faults that arise, are easily overlooked so that commercial stocks of a cultivar deteriorate relatively quickly (Parsons 2011). This problem is made worse because there is no registration authority for Lathyrus cultivars and they are introduced into cultivation without the rigour that applies, for example, to field pea (Pisum sativum) cultivars.

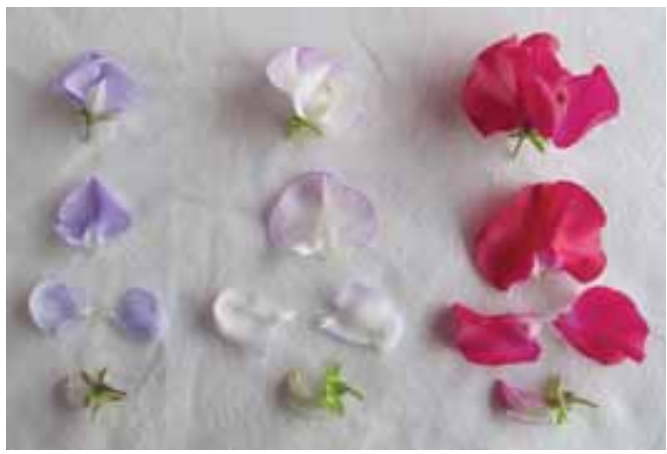

Fig. 2. Flowers forms in sweet pea: Grandiflora (Lady Grisel Hamilton), Semi-Grandiflora (Albutt Blue) and Spencer (Millennium)

Slika 2. Oblici cveta mirisnog grahora: grandiflora (sorta Ledi Grizel Hamilton), polu-grandiflora (sorta Elbat Blu) i spenser (sorta Milenijum)

Commendable effort has gone into conserving the diversity of forage and grain Lathyrus but there was no readily accessible seedbank conserving ornamental Lathyrus. In the UK and elsewhere, sweet pea commercialisation has been characterised by a relatively short cycle of cultivar introduction, deterioration over several generations and replacement by a new cultivar with the same flower colour. Such new cultivars may fill the same niche in the marketplace for flower colour but each cultivar has its own characteristics, for example adaptation to microclimate and different soils. The first-named author became concerned that cultivars were being lost and that the genepool was being reduced. He had been conserving other Lathyrus species since 1991, but in 1998 established a seedbank to conserve L. odoratus cultivars. Fortunately, Lathyrus seed stores very easily when placed in an air-tight container in an ordinary domestic freezer (Hammett 1979).

In 2005, this collection was recognised as a UK National Collection, trading as Roger 
Parsons Sweet Peas. It now consists of around 900 L. odoratus cultivars and around 100 taxa from other Lathyrus species. New accessions from around the world are always welcome. Over 100 stocks of annual Lathyrus, mostly L. odoratus cultivars, are grown each year. These are grown in very small quantities, usually between 10 and 60 plants of each cultivar, so that each plant can be assessed for being true to its original qualities. Unlike field cropping, the emphasis is on the quality of the seed stock rather than the quantity of seed produced. It might be thought that field-scale seed producers should do more to maintain the quality of their seed stocks but such neglect has created a niche market for Roger Parsons Sweet Peas. At the end of each season, fresh seed is returned to the seedbank and the surplus is sold. Customers include seed producers who want a true or improved stock of a cultivar that they can then send to be bulked up for field production. Roger Parsons Sweet Peas also retails direct to amateur gardeners since this provides a higher profit. A limited selection of cultivars and species is advertised on the website www. rpsweetpeas.co.uk and a mail order catalogue is sent each year to previous UK customers. This provides an opportunity to offer people species or colours that they were unaware existed and to encourage them to try something that is currently not popular. However, all this work is a personal domestic effort which makes it vulnerable to being lost.

\section{Opportunities for Lathyrus Breeding}

The seedbank provides access to perhaps the world's most diverse collection of material for this genus. Not content with conserving the fullest diversity, plant breeding provides an opportunity to increase the diversity. This may be from recognising the qualities of mutations that arise casually, but more importantly a small programme of hybridising takes place. Up to now, this has consisted mainly of introducing new colours into the late Spencer type that are so popular with UK gardeners, or improving the qualities of existing colours. In 2010, work began on breeding programmes for dwarf sweet peas and for early-flowering sweet peas.

This work is possible because the flowers of $L$. odoratus cultivars have self-pollinated by the time they are open. This allows cultivars to be grown alongside each other yet remain true from seed. There is a very small risk of some cross-pollination occurring which is why rigorous reselection of small batches of a cultivar is the best way to conserve it. In order to hybridise two cultivars, the petals of the seed-bearing flower must be unfurled while still in bud at a stage when the gynoecium is sufficiently mature to receive pollen but the anthers have not yet produced pollen (Fig. 3). The anthers are removed and then pollen from the pollen-bearing parent is applied to the stigma. The petals are then closed and the flower is allowed to develop normally, having of course been carefully labelled. Subsequent generations are grown and allowed to self-pollinate until single plant selections result in a seed stock that breeds true for the desired characters (Parsons 2011).

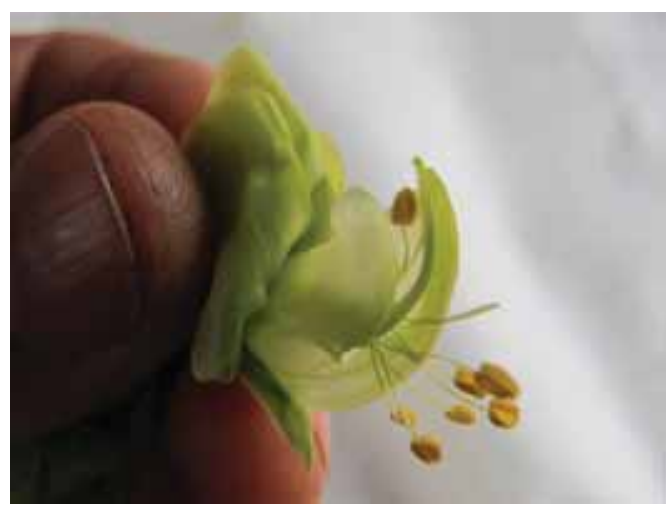

Fig. 3. A sweet pea flower ready for hybridization Slika 3. Cvet mirisnog grahora spreman za ukrštanje

There appears to be considerable potential for other people to engage in breeding new ornamental Lathyrus. There are several types of sweet pea that are not receiving the attention they merit. Very little work is being carried out on earlyflowering cultivars in the UK, which are not as popular there as the summer varieties. However, they have great popularity in other parts of the world and with commercial cut flower growers. Japanese cut flower growers are quite active with these but are reluctant to allow their cultivars to become available to their commercial competitors. In addition, there is very limited availability of summer-flowering Multiflora cultivars and, to the best of our knowledge, nobody is working on these. Some recent interest has been shown in improving dwarf and intermediate height cultivars, which are most popular in the USA, but there is considerable scope for the plant breeder to work on these.

The everlasting pea, L. latifolius, is a popular garden plant in the UK and is grown as a cut flower crop in some countries. Another perennial 
garden species is the dwarf spring pea, L. vernus. Both of these have a small number of colours that have arisen through mutation and it seems that their position reflects that of $L$. odoratus in 1800. However it is not simply the occurrence of mutations that has led to such diversity in L. odoratus but human intervention is needed to identify and secure desirable mutations. It may be that by conventional intra-specific hybridisation, other Lathyrus species can be induced to provide a broader range of colours and that other qualities can be improved, for example flower size in $L$. vernus (Fig. 4).

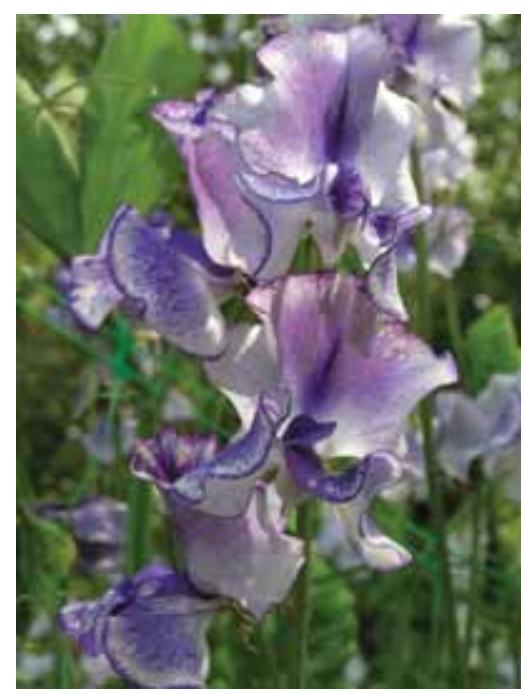

Fig. 4. L. odoratus 'Frances Kate' is a novel variety for 2011 and has Spencer flower form

Slika 4. Sorta mirisnog grahora Franses Kejt je novitet za 2011. godinu i poseduje spenser oblik cveta

New colours are arising in L. odoratus partly as a result of inter-specific hybridisation. Lathyrus species cannot easily be induced to hybridise but cultivars have now become available that arise from a cross between $L$. belinensis and L. odoratus, using embryo rescue (Hammett et al. 1994). Hybrid material tends to adopt the morphological features of one parent or another after a few generations but may still introduce novel qualities. Material from this particular cross is still being evaluated but the potential for resistance to powdery mildew (Erysiphe polygoni) has already been reported (Poulter et al. 2003). Personal observations suggest extended vase life may be possible.

Such plant breeding may also benefit research on other economically important genera of the tribe Fabeae (Smýkal et al. 2010) which, beside the genus Lathyrus, includes Pisum (pea), Vicia (vetch), Lens (lentil) and Vavilovia (vavilovia), among others. For example, a nice confirmation of the law on homology series in botanically related species, established by N. I. Vavilov nearly a century ago (Vavilov 1920), is the existence of the orthologous genes in sweet pea $(t)$ and field pea (t $t)$, both controlling the development of just the leaflets (Hofer et al. 2009) into a socalled 'tendril-less', 'acacia' or 'multijugate' leaf type (Fig. 5). This leaf type in field pea may be beneficial in breeding for increased forage yields (Mikić et al. 2010).

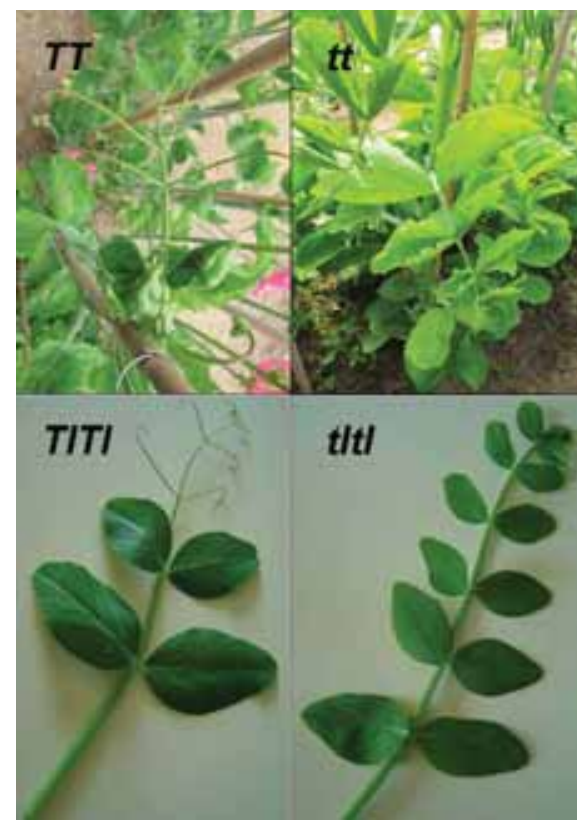

Fig. 5. Phenotypes of two orthologous genes in two close botanical legume relatives: normal leaves in sweet pea (TT) and field pea (TTL) and tendrilless leaves in sweet pea $(t t)$ and field pea (tltt) Slika 5. Fenotipovi dva ortologna gena dva bliska botanička srodnika: obični tip lista kod mirisnog grahora (TT) i gajenog graška (TTL) i bagremasti tip lista kod mirisnog grahora ( $t$ t i gajenog graška (tlt $)$ 


\section{Conclusions}

A considerable number of diverse ornamental forms of $L$. odoratus exist which require careful conservation if they are not to be lost. Other ornamental Lathyrus species may have potential for increasing their diversity. A seedbank has been established in the UK to conserve this diversity and make the material readily available to researchers and growers throughout the world. Conventional hybridisation provides an opportunity for the existing diversity in L. odoratus to be extended. Opportunities also exist to create improved decorative forms and new colours in some other species through intra-specific hybridisation. Inter-specific hybridisation within the genus is in its infancy but early results suggest exciting improvements might be introduced by this method. Such work might also provide benefits for comparative genomics in the tribe Fabeae.

\section{References}

Hammett K R W (1979): Seed Storage. NSPS Annual 1979: 37-38

Hammett K R W, Murray B G, Markham K R, Hallett I C (1994): Interspecific hybridisation between Latbyrus odoratus and L. belinensis. Int. J. Plant Sci. 155: 763-771

Hofer J, Turner L, Moreau C, Ambrose M, Isaac P, Butcher S, Weller J, Dupin A, Dalmais M, Le Signor C, Bendahmane A, Ellis N (2009): Tendril-less regulates tendril formation in pea leaves. Plant Cell 21: 420-428

Mikić A, Kosev V, Gantner R, Mihailović V, Smýkal P, Ambrose M (2010): Diversity and agronomic utility of leaf types in pea (Pisum sativum L.). Book of Abstracts, XXIVth Genetic Days, Brno, Czech Republic, 1-3 September 2010, 53

Parsons R (2000): Early History of the Sweet Pea. In Ball C. (ed.) National Sweet Pea Society Centenary Celebration 1900-2000. National Sweet Pea Society, Stockbridge, UK, 5-19

Parsons R (2009): Ornamental Latbyrus species. Grain Legumes 54: 6-7

Parsons R (2011): Sweet Peas - an Essential Guide. Crowood, Marlborough (in press)

Poulter R, Harvey L, Burritt D (2003): Qualitative resistance to powdery mildew in hybrid sweet peas. Euphytica 133: 349358

Smýkal P, Kenicer G, Mikić A (2010): Molecular taxonomy of the tribe Fabeae (Vicieae). Abstracts, Vth International Congress on Legume Genetics and Genomics, Pacific Grove, USA, 2-8 July 2010, 122

Vavilov N I (1920): The law of homology series in genetical mutability. Proceedings, All-Russia Congress on Breeding and Seed Production, 1, Saratov, Russia, 4-13 June 1920, 41-56

Wright W P (1912): A Book about Sweet Peas. Headley Brothers, London 


\title{
Očuvanje i oplemenjivanje ukrasnih vrsta roda Lathyrus
}

\author{
Rodžer Parsons ${ }^{1} \cdot$ Aleksandar Mikić $^{2}$ \\ ${ }^{1}$ Mirisni grahor Rodžera Parsonsa, Čičester, Velika Britanija \\ ${ }^{2}$ Institut za ratarstvo i povrtarstvo, Novi Sad, Srbija
}

Izvod: Ukrasne vrste roda grahor (Lathyrus) odlikuju se visokom učestalošću mutacija, što je dovelo do nastanka raznovrsnih ukrasnih formi od kojih pojedine zahtevaju pažljive mere očuvanja. U Velikoj Britaniji je osnovana banka semena sa ciljem da očuva diverzitet i učini materijal spremnim za korišćenje istraživačima i uzgajivačima širom sveta. Konvencionalno ukrštanje omogućava proširenje postojećeg diverziteta kod mirisnog grahora (L. odoratus). Postoje mogućnosti da se stvore usavršene ukrasne forme i nove boje kod nekih drugih vrsta putem unutarvrsnog ukrštanja. Međuvrsno ukrštanje unutar roda je još uvek u začetku, ali prvi rezultati nagoveštavaju da se ovim putem mogu načiniti izuzetni pomaci, ne samo u oplemenjivanju ovih vrsta, već i u uporednoj genomici tribusa Fabeae. Ključne reči: banka semena, grahor, Lathyrus, mirisni grahor, očuvanje, oplemenjivanje biljaka, semenska proizvodnja, ukrštanje 